\title{
An analysis of the successful 1992 Massachusetts tobacco tax initiative
}

\author{
Howard K Koh
}

\begin{abstract}
In November 1992, voters in Massachusetts (United States) passed a statewide tax initiative adding an extra 25 cents to the price of a pack of cigarettes. The Massachusetts Coalition for a Healthy Future, led by volunteers from the Massachusetts Division of the American Cancer Society, achieved this victory, despite a public anti-tax mood and $\$ 7.3$ million spent by the tobacco industry. The tax has since generated millions of dollars for tobacco education and control programmes, leading to acceleration of the decline of tobacco consumption in the state. An analysis of the passage of this initiative should help other states considering this approach to tobacco control.
\end{abstract}

(Tobacco Control 1996;5:220-225)

Keywords: tobacco tax; initiative petition

\section{Introduction}

In November 1992, voters in Massachusetts (United States) approved a statewide initiative that levied an extra 25 cent tax on cigarettes to fund new tobacco education and control programmes. Spearheaded by the Massachusetts Coalition for a Healthy Future, this victory made the state only the second in the country to raise the tobacco tax through the initiative process. Outspent by the tobacco industry by almost 10:1, the Coalition achieved victory despite the political inexperience of its lead organisation, the Massachusetts Division of the American Cancer Society (ACS). As the history of tobacco tax initiatives is young, an analysis of the creation, passage, and execution of the Massachusetts campaign can identify successful strategies potentially applicable to other states.

The initiative evolved in four phases:

(a) 1990: creation of the Massachusetts tobacco tax initiative;

(b) 1991 and 1992: establishment of the Massachusetts Coalition for a Healthy Future and the successful completion of signature petition drives;

(c) summer and autumn of 1992: the campaign;

(d) 1993-96: evolution of the Massachusetts Tobacco Control Program

\section{0: Creation of the Massachusetts} tobacco tax initiative

In 1990 Dr Blake Cady, newly elected president of the Massachusetts Division of the ACS and Professor of Surgery at Harvard Medical School,o first proposed the tax initiative as a new means for statewide tobacco control. At that time, rising $(\rho)$ lung cancer mortality rates had helped pusho statewide, age-adjusted cancer death rates past $\stackrel{\circ}{3}$ the death rates for heart disease. ${ }^{12}$ Despite the overall decline in smoking prevalence to $28.2 \%$, smoking-related illness caused $15 \%$ of all Massa- $\vec{\bullet}$ chusetts deaths (11000 per year) ${ }^{34}$ costing more. than $\$ 1.6$ billion in medical expenses and lost productivity. ${ }^{3}$

At the urging of Cady and Candace Pierce-Lavin (ACS Director of Government $\stackrel{0}{\circ}$ Affairs), the ACS Tobacco Control Task Force $\stackrel{\circ}{2}$ studied the lessons of previous tobacco tax ini- $\overrightarrow{\vec{O}}$ tiatives, with particular attention to the success 3 in California and the failure in Montana. The 1988 passage of Proposition 99 in California was propelled by a coalition of voluntary health $\mathrm{O}$ agencies, medical organisations, and environmental groups that collected more than a mil-o lion signatures to place the initiative on the $ᄋ$ ballot. Spending only $\$ 1.6$ million (in the face of $\$ 21.4$ million spent by the tobacco ? industry), the campaign used extensive media $\frac{5}{3}$ exposure to convince $58 \%$ of voters to favour the initiative. ${ }^{5-7}$ The extra 25 cents per pack generated more than $\$ 750$ million in the first year, $20 \%$ of which was intended to fund new tobacco control programmes, including $\frac{\text { o }}{0}$ counter-advertising through the media. As a result, overall tobacco consumption statewide $\stackrel{\sim}{\sigma}$ declined by more than three times the national $N$ average..$^{5-7}$ However state deficits and tobacco $\underset{\omega}{N}$ industry political pressure ${ }^{8}$ motivated the 0 governor and the legislature to divert more than $\$ 220$ million out of the tobacco education $\stackrel{0}{\mathbb{D}}$ account, prompting a round of lawsuits.

Meanwhile, in 1990, Montana voters 0 defeated Initiative 115, a proposal to raise the $\frac{\vec{D}}{\mathrm{D}}$ cigarette tax by 25 cents (59\% to $41 \%$ ). ${ }^{9}$ After- $\frac{?}{?}$ wards, leaders from that campaign strongly $\stackrel{\odot}{\circ}$ recommended three tactics in future initiatives: $\stackrel{0}{\circ}$ firstly, build a broadbased coalition that could 8 provide the proper political and financial support; secondly, enlist experienced media handlers; and thirdly, anticipate a well- $?$ financed tobacco industry attack that will frame the initiative as a tax issue, not a health issue. $^{9}$ 
With these lessons in mind, the ACS Tobacco Control Task Force favoured a tax initiative for three reasons.

(1) Economic analyses have documented price elasticity, that is, increasing the price of cigarettes led to decreased cigarette consumption (a sales drop of 0.75 packs per capita for each 1-cent increase in cigarette taxes). ${ }^{10-12}$ Some studies indicate that teenagers are at least as cost sensitive as adults, and perhaps more so. ${ }^{13-14}$

(2) The tax would generate more than $\$ 100$ million dollars annually for a new Health Protection Fund to create statewide tobacco control programmes (including an anti-smoking media campaign and health education for schoolchildren).

(3) Over the years, the traditional state legislative process had rejected proposals to raise the cigarette excise tax. In Massachusetts, stable excise taxes for almost a decade left room for upward movement.

In a 1990 memorandum to the ACS detailing the two-year process required to pass the initiative, Pierce-Lavin urged that this activity receive the highest priority. Initially, ACS volunteers statewide voiced fears that advocacy would compromise fundraising, tarnishing the organisation as a political activist group. After extensive discussion with the ACS board of directors and the 42 local units (representing some 12000 statewide volunteers), the Massachusetts division agreed to spearhead the initiative, as long as opinion polls showed strong popular support and a broad coalition could provide the necessary human resources and funding. ${ }^{15}$

In April 1991, the political consulting firm Marttila and Kiley conducted a statewide poll which found that nearly $70 \%$ of Massachusetts registered voters favoured the initiative. Even after hearing eight of the most common arguments against the tax, $54 \%$ still favoured it, foreshadowing the actual vote by the same proportion on election day in $1992 .{ }^{15}$

1991 and 1992: Establishment of the Massachusetts Coalition for a Healthy Future and successful completion of signature petition drives

Buoyed by polling results, the ACS formed the Massachusetts Coalition for a Healthy Future, which ultimately united nearly 250 state businesses, human services groups, health organisations, hospitals, and community organisations. Pierce-Lavin temporarily left the ACS to serve as the Coalition's campaign manager. An executive committee of the Coalition, consisting of the Massachusetts Medical Society, Blue Cross and Blue Shield of Massachusetts, and the Massachusetts Association of Health Maintenance Organizations (HMOs), ${ }^{15}$ contributed a minimum of $\$ 20000$ each. This strategy committee also recruited political and legal consultants. Overtures to Massachusetts' many medical institutions yielded few additional groups willing to commit financially to the controversial realm of initiative politics. However, the Group Against Smoking Pollution (GASP) and the Massachu- setts Nurses Association contributed substantial donations in kind. ${ }^{\star}$ 궁

Coalition members received as urance that the prominent statewide group Citizens for Limited Taxation would not opp the initiative. Lawyers for the Coalition the crafted the proper wording of the initiative,, anticipating inevitable legal challenges by the tobacco industry. Because the Massachusefts state constitution prohibits earmarking tax evenues for specific purposes, the initiatic proposed establishing a Health Protection Fynd from tax revenues "subject to appropriatioff by the state legislature" without legally maprdating that money be spent on tobacco contrô. ${ }^{16}$

Massachusetts law required 000 voter signatures of support ( $3 \%$ of the total voter turnout in the previous statewide glection) ${ }^{17}$ to place the initiative on the statewride ballot. Because challenges to signaturesthad stalled previous efforts in Oregon, Cgorado, and Arkansas, Coalition leaders aimed to gather twice that number as a buffer agaffist disqualifications.

The initiative process required $\stackrel{\mathbb{D}}{\mathrm{D}}$ wo signature drives. The first, starting shtly before election day, in November 1991, Tasted for 60 days. Although each contributing\&rganisation targeted a certain predefined numBer of signatures, ACS volunteers and staff directed by Pierce-Lavin ultimately procures the vast majority. The drive gathered omore than 120000 signatures ${ }^{151618}$ at sett落gs ranging from supermarkets and holiday 2 parades to influenza immunisation clinics $\vec{a}$ and school registration days. The sheer 3 volume of signatures deterred a team of ₹7andwriting experts $^{14}$ hired by the tobacco industry; city and town clerks eventually certifieg more than $90 \%$.

State law ${ }^{17}$ required a second si fônature drive in the spring of 1992 (6 May 17 June), which gained over 25000 , much nere than the required 12000 . Altogether, $\frac{0}{-}$ volunteers collected nearly 150000 signaturgs, the most for any Massachusetts initiative carmpaign. On the 1 July deadline, more than 108 children of the "Smoke-Free Class of 2000" sponsored a "kids only" press conference andPdelivered a petition-filled red wagon to the office of the Secretary of State. ${ }^{19}$ The tobacco Tax initiative became "Question 1" on the autumn Massachusetts ballot.

As expected, the tobacco indwstry countered. Their proposed compromise of a lower tax increase, dedicating a percentage to schoolbased tobacco control prografnmes, was ignored as a diversionary tactic. Then, industry lawsuits contending that the propsed tax was

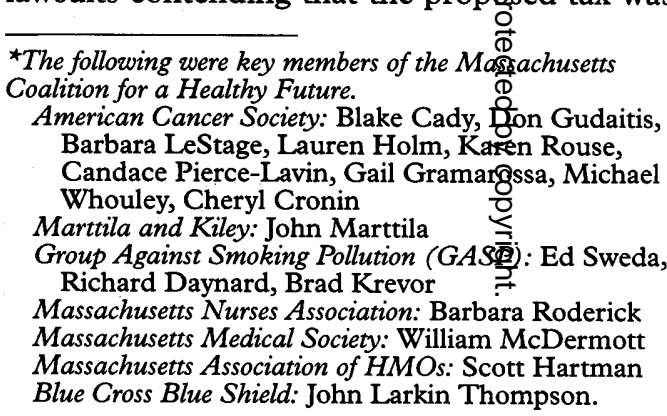


Arguments and strategies in the 1992 Massachusetts tobacco tax initiative

\begin{tabular}{|c|c|}
\hline Committee Against Unfair Taxes & Massachusetts Coalition for a Healthy Future \\
\hline $\begin{array}{l}\text { Arguments } \\
\text { The tax is unfair } \\
\text { The tax is regressive } \\
\text { The tax money could not legally be mandated for tobacco education } \\
\text { - Politicians shouldn't be trusted to spend your tax money } \\
\text { - Small business would lose money with cross-border sales } \\
\text { Leave smokers alone } \\
\text { Strategies } \\
\text { - Employ Jack Flood, former Massachusetts House Taxation Chairman, as } \\
\text { spokesman } \\
\text { - Appeal to choice and smokers' rights } \\
\text { - Focus on taxes, minimising mention of the word tobacco }\end{array}$ & $\begin{array}{l}\text { - Cancer is unfair } \\
\text { - Cancer is regressive } \\
\text { - Tobacco addicts children and the poor } \\
\text { Tobacco education could especially help children and minorities } \\
\text { - Gain support of broadcast media and newspapers } \\
\text { - Emphasise protecting children as the campaign theme } \\
\text { - Enlist prominent health figures } \\
\text { - Engage health professionals (doctors/nurses) to demonstrate publicly on } \\
\text { - Frame the initiative as an explicit battle between the ACS and the tobacco } \\
\text { industry }\end{array}$ \\
\hline
\end{tabular}

unconstitutional for earmarking revenues specifically for anti-smoking programmes were dismissed by the Massachusetts Supreme Judicial Court in July 1992.

\section{Summer and autumn of 1992: the campaign}

Committee Against Unfair Taxes

The Massachusetts Coalition for a Healthy Future squared off against the Committee Against Unfair Taxes, organised and funded by the tobacco industry. The committee's strategy capitalised on the anti-tax climate of the state. Spokesperson Jack Flood, former gubernatorial candidate and former House of Representatives chairman of the Massachusetts Legislature's Joint Committee on Taxation, led arguments that the tax was unfair and regressive (disproportionately affecting people with low incomes) (table). As expected, he raised the spectre of class warfare, arguing that this regressive tax pitted upper middle class liberals (mostly white) against lower middle class working people (mostly minority). ${ }^{16} 18$ Tapping into rising public cynicism about elected officials, Mr Flood further warned that tax-generated monies would be diverted from their intended purposes, as had occurred in California after the passage of Proposition 99. Mr Flood reminded voters that politicians diverted revenues from a 1991 Massachusetts

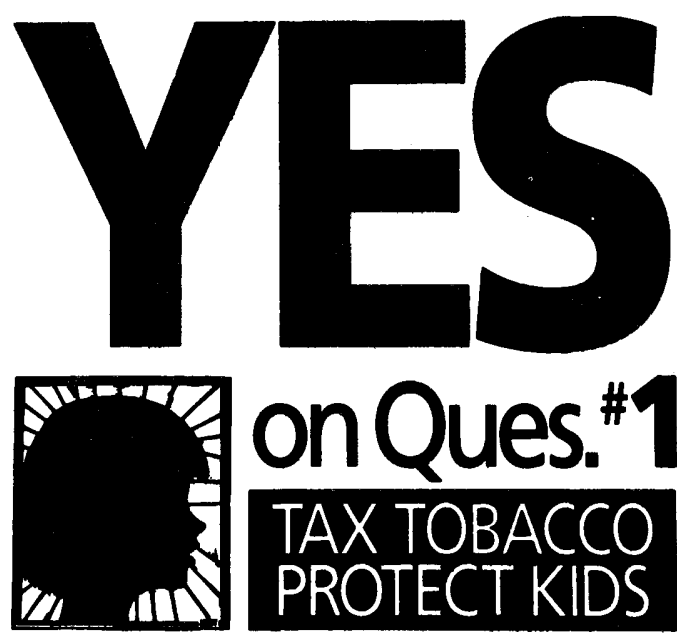

Figure 1 Logo/bumper sticker for the Question 1 campaign (reprinted with permission from the American Cancer Society, Massachusetts Division). gasoline tax hike intended to fund new roads and bridges to balance the budget. ${ }^{20}$ On prominent committee television advertisement featured water disappearing down a sink음 suggesting that any tobacco tax money would be similarly disposed. Other argumentep suggested that the tax would harm Massachu유 setts small businesses by motivating people tơ buy cheaper cigarettes outside the state. Lastly@ they portrayed smokers as beleaguered victims, and argued to "let the smokers hack ine peace". ${ }^{21}$

\section{MassachusetTs Coalition for a Healthy}

FUTURE

In response to the charges of unfair taxes, the Massachusetts Coalition for a Healthy Future focused on the unfairness of the $\$ 45$ billion tobacco industry, their addiction of children and their efforts to buy the election. The Coa? lition maintained that cancer was far more unfair and regressive than any $\operatorname{tax}$ disproportionately afflicting the poor and minority groups while burdening taxpayers? with huge costs (table). Questioning the moti vation of the industry to protect the poor or taxe freedoms, the Coalition argued that new health? and education programmes from a tax could in fact, benefit the poor and minority groups.

The total budget for the Massachusetts Coa lition for a Healthy Future was $\$ 8000065$ (including contributions in kind), with only $\$ 40000$ from private donors (C Pierce-Lavin personal communication, March 1996) N Included in the Coalition's budget was an unprecedented donation of $\$ 250000$ in the final hours of the campaign from the nationaf office of the American Cancer Society, keenly aware of the nationwide ramifications of Massachusetts success. In contrast, the Committee Against Unfair Taxes waged a $\$ 7.30$ million campaign. ${ }^{22}$

Financial pressures forced the Coalition tom seek free media. Meetings with editorial board of major newspapers, television stations, and radio outlets gained critical support. Of note the Boston Globe (with $40 \%$ of the state's read ership) published nine favourable editorials as well as steady news coverage and many? supportive commentaries. ${ }^{15}$ The Boston Herald and daily newspapers in major cities such as Worcester, Springfield, New Bedford, and Fall 
River publicised the initiative, thereby reaching an audience unattainable through paid advertising alone. Furthermore, the Coalition pursued newspaper endorsements, letters to the editor, calls to radio talk shows, and press events.

The Coalition focused on children as their theme, promoting a slogan of "Tax tobacco-protect kids" (figure 1). Related publicity events included a children's press conference and a teleconference starring Keshia Knight-Pulliam, who was honorary class president of the Smoke-Free Class of 2000, and who played the daughter of Bill Cosby in the actor's popular television programme. ${ }^{15}$

Other Coalition efforts underscored the David-versus-Goliath scenario. Weekly updates publicised the large sums of tobacco industry money being spent around the state. A regular newsletter updated all Coalition members on effective responses to tobacco industry arguments. ${ }^{15}$ To draw on the public's special trust in nurses, members of the Massachusetts Nurses Association, in their white uniforms, held a press conference in front of Mr Flood's office and challenged him to visit their cancer wards. ${ }^{15}$ After negotiations with all three major television stations in the state, one imposed a limit on the purchase of all air time related to Question 1 to offset the overriding monetary advantage of the tobacco industry. For the first time in recent memory, health professionals in white coats joined volunteers to hold signs at busy highways and intersections. Doctors also wrote letters to the editor in virtually every daily and weekly newspaper in the state, placed campaign literature in their patient waiting areas, and distributed preprinted "prescriptions" (figure 2).

The Committee responded with a variety of strategies. Television advertising designed for Massachusetts liberalism urged tolerance, equating images of Martin Luther King, Jr, pro-choice (favouring abortion rights) activists, and patients with AIDS to "smokers' rights". ${ }^{1523}$ In collaboration with the tobacco industry, an out-of-state, ultra-conservative,

TELEPHONE 555-YES 1

\section{YOUR DOCTOR}

REG. NO AS 11111111

111 Main Street

NAME Anytown, Massachusetts 02111

\section{ADDRESS} AGE

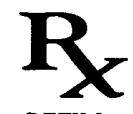
REFILL

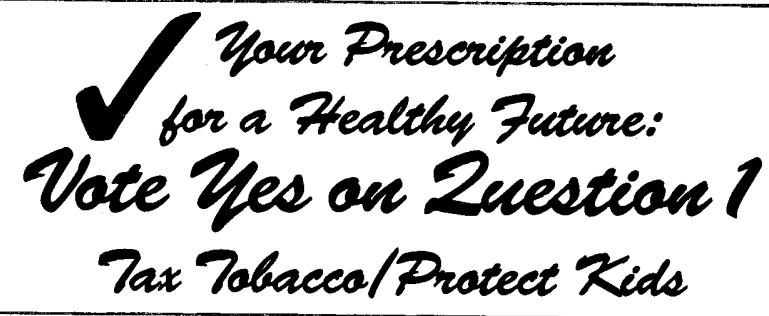

Interchange is mandated unless the practitioner writes the words "No Substitution" in this space There is No Substctution for a Healthy Futurell

Figure 2 "Prescriptions" distributed by doctors urging passage of Question 1 (reprinted with permission from the American Cancer Society, Massachusetts Division).
Catholic voters organisation distributed thousands of letters claiming that-Question 1 would fund abortion counselling क्ञ⿰冫欠 condom distribution in schools as part of Eomprehensive school health education. ${ }^{15}$

Several vivid public debates persinalised the battle between spokespersons Floot and Cady. In one exchange, Mr Flood dismissed the bowtie-bedecked Cady and raised the spectre of class warfare by charging that "only the bow-tie and brie crowd" would faIn the same debate, responding criticisms that the committee's discussion cabout taxes avoided any mention of tobaroco, Flood snapped "Everyone wants me to say tobacco, tobacco, tobacco. Everybody hap now? But the question is still taxes, taxes, ta庐es, taxes."24 Declining public opinion of Mriflood was epitomised by a Boston Globe polifical cartoon depicting him as a monkey dancin今్ the tune of the tobacco industry's organ gripder.

National figures provided public backing. US Surgeon General Antonits Novello, although officially unable to endo Question 1 , visited Boston to draw attention to tobacco control efforts. Former US Surgeoge General C Everett Koop also voiced his suppört and later published an article stating tobacc\& taxes were "good for you".15 Former US \&enator and presidential candidate Paul Tsongs, a cancer survivor and one of the mosf respected politicians in the state, supportedouestion 1 as the campaign's honorary cloairman. In particular, his angry response tब a tobacco industry brochure urging "tol $\overrightarrow{\text { frrance" by }}$ depicting a political rally featuring one of his campaign signs galvanised public the $\operatorname{tax}^{25}$

As election day approached, theơ Committee Against Unfair Taxes stepped up antQuestion 1 media advertising, causing a Ôprecipitous erosion of public support (figgre 3). In response, the Marttila and iley firm conducted focus-group sessions uncovering two critical points: firstly, even ingthe closing weeks, many voters still did not grasp that the ACS served as the primary ponsor of Question 1; secondly, more than 7.్ర\% of voters trusted the ACS to direct püblic health smoking issues, a public credility rating higher than for other anti-smoking groups and dwarfing the $4 \%$ rating for tope tobacco industry. Hence the Coalition ndecided to reframe the initiative. Volunteers scisbsequently distributed one million brochures explicitly urging citizens to "Help the American Cancer Society Fight the Tobacco Industro".

With less than a month to go, the Coalition released their only television adxzertisement. This piece opened with a shadowymontage of cigarette packages arrayed like tombstones in a graveyard, urged voters to supportकuestion 1 , and closed with a full frame of the ACS logo. Two days before the election, a fullopage advertisement in most of the state's dail thewspapers argued the effectiveness of the Wgarette tax hike in California. On election day, 3 November 1992, Question 1 passed by $54 \%$ to $46 \%$ with the support of almost one and a half million Massachusetts citizens (figure 4). ${ }^{17}$ 


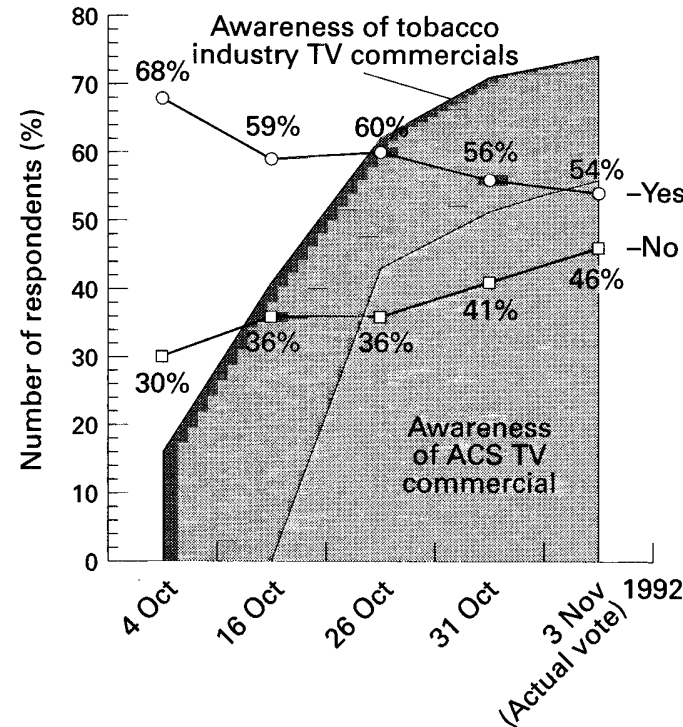

Figure 3 Trends in support for Question 1 (1992) (reprinted with permission from Marttila and Kiley, and the American Cancer Society).

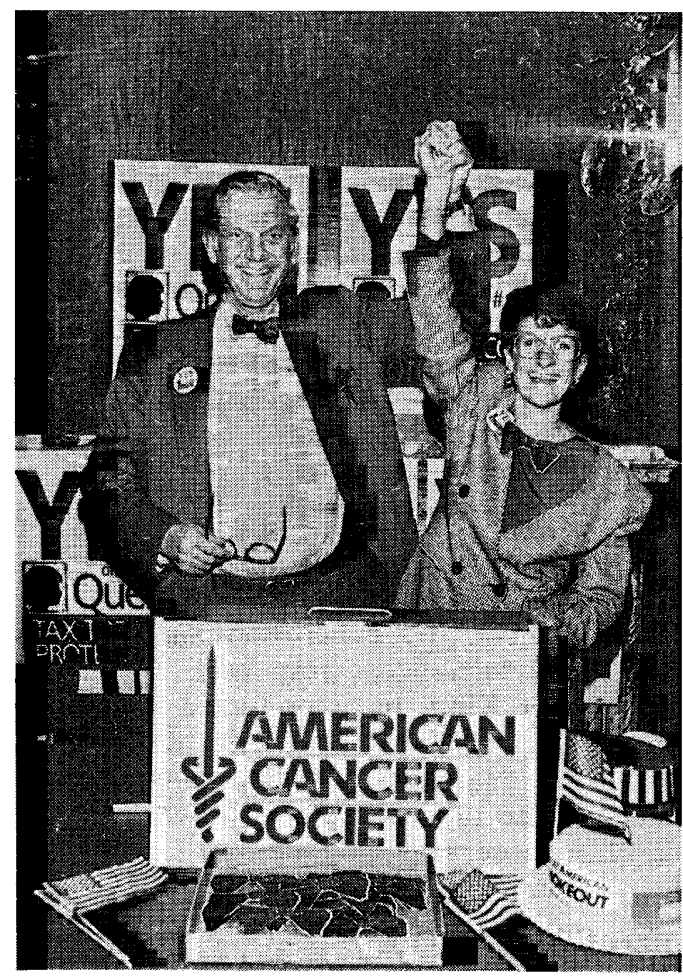

Figure 4 Dr Blake Cady and Candace Pierce-Lavin, leaders of the Question 1 campaign, celebrate passage of the tobacco tax initiative. (Reprinted with permission from the American Cancer Society.)

\section{3-96: Evolution of the Massachusetts Tobacco Control Program}

As of 1 January 1993, the Massachusetts cigarette excise tax rose to 51 cents a pack-one of the highest in the nation at the time. Post-election polling ${ }^{23}$ showed that $64 \%$ (not $54 \%$ ) of voters recalled voting in favour of Question 1, evidence of a so-called "halo effect".

From the first 18 months of tobacco taxes, $\$ 96$ million from the new Health Protection Fund launched the Massachusetts Tobacco Control Program (MTCP). This included \$33 million to the Department of Education for comprehensive school health education, $\$ 28$ million for local community tobacco control initiatives, $\$ 18$ for media counter-advertisingand $\$ 5.5$ million for statewide initiatives including a Smoker's Quitline. Tax money als\& funded a tobacco education clearinghouse research and evaluation, Drug Abuse Resistance Education (DARE) programme administered by local police departments, and other health programmes, such as those supporting community health centres, sub stance abuse treatment, the Women, Infants and Children Supplemental Nutrition pro은 gramme, breast cancer and AIDS researchp and family health). A full description of the MTCP, beyond the scope of this article, will be forthcoming in future publications (Harris Connolly G, personal communication, 1996)

However, the Massachusetts Statehouse has? now become the crucial arena where tobacco industry lobbyists, tobacco control advocates public health officials, and politicians grapplo for control over the roughly $\$ 10$ million per month generated from the tax. The stark reales ity that the legislature ultimately controls these tobacco tax dollars has led Question $B$

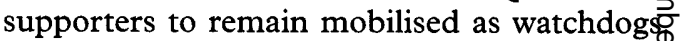
Political struggles caused the $\$ 96$ million budget for fiscal year (FY) 1994 to fall steadil 4 to $\$ 77$ million (FY95), then to $\$ 76 \mathrm{M}$ (FY96), and now to $\$ 67$ million (FY97). In addition, b8 appropriating increasing amounts of tas dollars to non-tobacco health programmes, the legislature essentially has pitted health groups against each other to fight about how monep should be appropriated. ${ }^{26}$

Early data showed that cigarette sales dropped by $11 \%$ and $15 \%$ in October and November of 1992 (compared with the same. period in 1991) probably reflecting tho Coalition's activity. ${ }^{27}$ Moreover, since Januaro 1993 (when the new tax was initiated and the MTCP began), per capita cigarette consumpo tion has dropped by at least $17 \%$, the larges single decline in Massachusetts history and rate three times higher than predicted. ${ }^{28}$

\section{Summary}

In the final analysis, what factors led to successful passage for the Coalition ? $^{29}$

(1) The timing was right. After decades of pub? lic education linking smoking to adverse. health outcomes (and newer reports linking environmental tobacco smoke tou disease), public opinion about the tobacco్ industry was at an all-time low Non-smoking had become the statewides norm, with $75 \%$ of the population abstain ing.

(2) Dedicated leaders and volunteers created a0 strong coalition. The resources of the Coalio tion, led by Cady, Pierce-Lavin, and the ACS, made the initiative victory achieve able. Cady, a senior Harvard professor an cancer surgeon, enhanced the image of the campaign as a mainstream effort (figure 4). The campaign capitalised on the publis. trust in the ACS by directly pitting it? image against that of the tobacco industry, and successfully coordinating thousands of ACS volunteers. The Coalition, which 
provided dollars, momentum, and visibility during the campaign, became even more important post-victory in holding legislators accountable to the promise of Question 1.

(3) Polling, complemented by focus groups, helped shape a campaign framed as one that protected children. Initial polls indicated wide support of the tax and the feasibility of this initiative. Continued polling helped guide and refine a campaign strategy that never blamed the smoker, but rather painted the tobacco industry as the villain. Never avoiding the word "tax", the Coalition rather linked it to the health of children. In so doing, the Coalition successfully upheld health issues as paramount to possible adverse effects on small business, smokers' rights and cross-border sales.

(4) The active volunteer involvement of health professionals kept the emphasis on health issues, not simply tax issues. The unprecedented work of doctors, nurses, and other health professionals, particularly in their letters to editors and their public demonstrations in white coats and uniforms, kept the focus on health. Their involvement dramatised the health benefits of Question 1.

(5) Legal help was critical. Strong legal and political consultation helped meet the formal demands of the initiative process, such as proper wording.

(6) Publicity events yielded free media coverage. The strong support of many media outlets, especially the Boston Globe and the television stations, galvanised public awareness and provided the intense level of publicity needed to counter the anti-tax advertising.

The passage of Question 1, in addition to the passage of Proposition 99 in California, has sparked interest in similar initiatives elsewhere around the country. In 1994, a similar tobacco tax initiative was passed in Arizona. In addition, a 50-cent increase in the state cigarette tax was approved by voters in Michigan in March 1994 as part of a multifaceted ballot initiative to replace property tax revenues with revenues from other taxes (especially sales and tobacco taxes). Hence, initiatives have now succeeded in four states while failing in others, presenting lessons for public health professionals contemplating future initiatives. ${ }^{29}$ For Massachusetts, the initiative has opened a new dimension for tobacco control. The new climate may have contributed to the 1996 Massachusetts legislative approval of yet another 25-cent state cigarette tax increase (to 76 cents) to fund improvements in healthcare access for uninsured children and the elderly poor. Despite continuing major obstacles to retain funding, to implement programmes, and to evaluate their effectiveness, tobacco tax initiatives offer new avenues to improve public health for the future.
Sponsored in part by the Judge Bernard Cohen Research Fund. I thank Alan Geller, Karen Rouse, Lauren Holm, Don Gudaitis, John Marttila, Kathy O'Connor, Gail Gramerossa, Candace Pierce-Lavin, Lori Fresina, Stanley Shmoshkiss, Barbara LeStage, Jack Nicholl, Representative John MCDonough, Brad Krevor, Ed Sweda, John Bloom, Judge Bernardacohen, and Drs Blake Cady, Robert Lew, Greg Connolly, an $\mathrm{P}$ Al Winder for their comments on this paper. I am also gratef to Dr Claudia Arrigg for unending encouragement and supp $\overline{\oplus r}$.

$\underset{\vec{\sim}}{\stackrel{\vec{S}}{+}}$

1 Massachusetts Department of Public Hglth, Bureau of Health Statistics. Advanced data set, 991 and 1992 Boston, Massachusetts:

Kong, D. Cancer death rate in Massachuse $\frac{\omega}{15}$ overtakes that of heart disease. Boston Globe 1992 Nov

3 Massachusetts Department of Public Helth, Bureau of Health Statistics. Smoking: death, disease, cand dollar. 1992. Boston, Massachusettes: DPH.

4 Massachusetts Department of Public Health Behavioral risk factor surveillance system report. 1992. Boston, Massachusetts: DPH.

5 Flewelling R, Kenney E, Elder J, et al. Fir整year impact of the 1989 California cigarette tax increase on cigarette consumption. Am $\mathcal{F}$ Public Health 1992;82:86் 9 .

6 Traynor M, Glantz S. The developmentiand passage of Proposition 99, California's tobacco tax inutiative. $\mathcal{F}$ Health Politics Policy Law. 1996;21:543-85.

7 Glantz SA. Changes in cigarette consumption, prices, and tobacco industry revenues associated "⿹ Proposition 99. Tobacco Control 1993;2:314-14.

8 Begay ME, Traynor MP, Glantz SA. The tobacco industry, state politics, and tobacco education in Palifornia. $A m$ Public Health 1993;83:1214-21.

9 Moon RW, Males MA, Nelson DE. The 190 Montana initiative to increase cigarette taxes: lessoneffor other states and localities. $\mathcal{F}$ Public Health Policy 1993\$4:19-33.

10 Peterson DE, Zeger SL, Remington PL, etal. The effect of cigarette tax increases on cigarette sales, 1055 to $1988 . A m$ ¥Public Health 1992;82:94-6.

11 Lewit EM, Coate D. The potential for using excise taxes to reduce smoking. Health Economics 1982; $121-45$.

12 Kaiserman MJ, Rogers B. Tobacco consu角ption declining faster in Canada than in the US. Am F Pu更ic Health 1991 81:902-4.

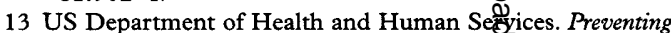
tobacco use among young people. A report of he Surgeon General. Atlanta, Georgia: Public Health Serfice, Centers for Disease Control and Prevention, Office $\overline{g n}$ Smoking and Health, 1994 (US Government Printing Office No S/N 017-001-00491-0.)

14 Coalition on Smoking or Health. Saving live and raising revenue: the case for major increases in state dim federal tobacco taxes. Washington, DC: Coalition on Smoking or Health, taxes. Washington, DC: Coalition on Smaking or Health,
1993.

15 Rouse K. Against all odds, victory for the ggod guys. Cancer News 1993;47:11-14.

16 Tisei, R. Inside the State House. Stoneham Sodependent 1992 Oct 15.

17 Elections Division. Public Document No. Massachusetts Elections Statistics 1992. Boston, Massachisetts: Office of Massachusetts Secretary of State, 1992.

18 Phillips F. Tobacco firms ready to battle b్kkers of hike on cigarette tax. Boston Globe 1992 May 4 .

19 Locy T. Signatures ensure four referendugins. Boston Globe 1992 Jul 2.

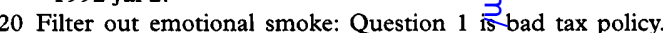
The Standard Times (Bedford, Massachusetts) 1992 Oct 7.

21 Beam A. Question 1 goes too far. Boston Glgbe 1992 Oct 5.

22 Begay ME, Glantz S. Question 1 tobacco 0 ducation outlays from the 1994 fiscal year to the 1996 fiscaEtear. Monograph series. Amherst Massachusetts: School of Public Health and Health Sciences, University of Maßsachusetts, Aug and

23 O'Connor, B. Ballot questions give voters foice in shaping policy. Bay State Banner (Boston, Mas6achusetts) 1992 Oct 29.

24 Aucoin D. Cigarette tax increase is hailed, hit at debate. Boston Globe 1992 Oct 23.

25 Phillips F. Tsongas rips tobacco industryxtobbyist. Boston Globe 1992 Oct 29.

26 McGrory B. Tobacco industry assault expected. Boston Globe 1992 Nov 8.

27 Aucoin D, Phillips F. Cigarette sales down Boston Globe 1992 Dec 18.

28 Harris J, Connolly G, Brooks D, Davis B. Cqgarette smoking before and after an excise tax increase and an anti-smoking campaign-Massachusetts 1990-1996. OMMWR 1996; 45:966-70.

29 Pierce-Lavin C, Koh H, Cady B. An analy of the successful 1992 Massachusetts tobacco tax initiatve. In: Slama K ed. Tobacco and health. Proceedings of the world conference on tobacco and health, 10-14 October 7994 . New York: Plenum Press, 1995:959-60. 